\title{
The nucleotide sequence and genome organization of Plasmopara halstedii virus
}

\author{
Marion Heller-Dohmen ${ }^{1,2^{*}}$, Jens C Göpfert ${ }^{1}$, Jens Pfannstiel ${ }^{3}$, Otmar Spring ${ }^{1}$
}

\begin{abstract}
Background: Only very few viruses of Oomycetes have been studied in detail. Isometric virions were found in different isolates of the oomycete Plasmopara halstedii, the downy mildew pathogen of sunflower. However, complete nucleotide sequences and data on the genome organization were lacking.

Methods: Viral RNA of different $P$. halstedii isolates was subjected to nucleotide sequencing and analysis of the viral genome. The N-terminal sequence of the viral coat protein was determined using Top-Down MALDI-TOF analysis.

Results: The complete nucleotide sequences of both single-stranded RNA segments (RNA1 and RNA2) were established. RNA1 consisted of 2793 nucleotides (nt) exclusive its 3' poly(A) tract and a single open-reading frame (ORF1) of $2745 \mathrm{nt}$. ORF1 was framed by a $5^{\prime}$ untranslated region (5' UTR) of $18 \mathrm{nt}$ and a $3^{\prime}$ untranslated region ( $3^{\prime}$ UTR) of $30 \mathrm{nt}$. ORF1 contained motifs of RNA-dependent RNA polymerases (RdRp) and showed similarities to RdRp of Scleropthora macrospora virus A (SmV A) and viruses within the Nodaviridae family. RNA2 consisted of 1526 nt exclusive its $3^{\prime}$ poly(A) tract and a second ORF (ORF2) of $1128 \mathrm{nt}$. ORF2 coded for the single viral coat protein (CP) and was framed by a $5^{\prime}$ UTR of 164 nt and a 3' UTR of 234 nt. The deduced amino acid sequence of ORF2 was verified by nano-LC-ESI-MS/MS experiments. Top-Down MALDI-TOF analysis revealed the N-terminal sequence of the CP. The N-terminal sequence represented a region within ORF2 suggesting a proteolytic processing of the CP in vivo. The $\mathrm{CP}$ showed similarities to $\mathrm{CP}$ of SmV A and viruses within the Tombusviridae family. Fragments of RNA1 (ca. $1.9 \mathrm{~kb}$ ) and RNA2 (ca. $1.4 \mathrm{~kb}$ ) were used to analyze the nucleotide sequence variation of virions in different $P$. halstedii isolates. Viral sequence variation was $0.3 \%$ or less regardless of their host's pathotypes, the geographical origin and the sensitivity towards the fungicide metalaxyl.

Conclusions: The results showed the presence of a single and new virus type in different $P$. halstedii isolates. Insignificant viral sequence variation indicated that the virus did not account for differences in pathogenicity of the oomycete P. halstedii.
\end{abstract}

\section{Background}

Only very few species within the Oomycetes are known to host virus-like elements such as virus-like particles (VLPs), double-stranded RNA (dsRNA) or singlestranded RNA (ssRNA) (for details see [1]). So far, only the virions of Sclerophthora macrospora and Plasmopara halstedii have been studied more in detail.

Sclerophthora macrospora virus A (SmV A) virus B $(\mathrm{SmV} \mathrm{B})$ are the only virions of Oomycetes of which the genome has yet been fully characterized $[2,3]$. They were isolated from Japanese isolates of S. macrospora, the downy mildew pathogen of Oryza sativa and other species

\footnotetext{
* Correspondence: hellerdo@msu.edu

'Institute of Botany, University of Hohenheim, 70593 Stuttgart, Germany

Full list of author information is available at the end of the article
}

within the Poaceae family. Both, SmV A and SmV B were isometric and used ssRNA to encode their viral genomes $[4,5] . \mathrm{SmV} \mathrm{B}$ featured one coat protein $(\mathrm{CP})$ of $41 \mathrm{kDa}$ and one ssRNA segment of 5533 nucleotides (nt) encoding two large open-reading frames (ORF). Two CP (43 kDa and $39 \mathrm{kDa}$ ) and three segments of ssRNA were found to set up SmV A. RNA1 consisted of 2928 nt and two ORF (ORF1a and ORF1b). ORF1a contained the motifs of the RdRp. The latter showed some similarity in the amino acid sequence to the RdRp of Nodaviridae. RNA2 consisted of $1981 \mathrm{nt}$ and a single ORF (ORF2) which encoded the CP. The CP of SmV A showed similarities to CP of viruses within the Tombusviridae family. RNA3 consisted of 977 nt but no ORF suggesting it as a satellite RNA [3-5].

\section{Ciomed Central}

() 2011 Heller-Dohmen et al; licensee BioMed Central Ltd. This is an Open Access article distributed under the terms of the Creative Commons Attribution License (http://creativecommons.org/licenses/by/2.0), which permits unrestricted use, distribution, and reproduction in any medium, provided the original work is properly cited. 
P. halstedii is a worldwide distributed pathogen with a broad spectrum of pathotypes (physiological races) [6], causing sunflower downy mildew infections. Almost 20 years ago, isometric virions were found in a single North American pathotype of P. halstedii [7]. The CP was determined to consist of a $37.5 \mathrm{kDa}$ polypeptide and RNA was determined to encode the viral genome $[8,9]$. A more recent screening of $P$. halstedii isolates from different countries showed the occurrence of morphologically and biochemically indistinguishable virions in all samples independent of their host's origin or pathotype or fungicide tolerance [1].

The virions were isometric and measured approximately $37 \mathrm{~nm}$ in diameter. One polypeptide of ca. 36 $\mathrm{kDa}$ and two segments of ssRNA (3.0 and $1.6 \mathrm{~kb})$ were detected. Comparison of a partial nucleotide sequence confirmed the uniformity of the virions found in P. halstedii isolates. In addition, the deduced amino acid of this RNA fragment indicated similarities to a part of the CP of SmV A [1]. However, final analysis of the relationship of the Plasmopara halstedii virus (PhV) to other viruses was constricted due to lack of full genomic data. Here we report on the complete nucleotide sequence and genome organization of $\mathrm{PhV}$ and its relationship to other viruses. Additionally we report on the extremely low genetic variation of PhV within several $P$. halstedii isolates of different origin and pathogenicity.

\section{Methods}

\section{Origin and culturing of the used fungal isolates}

$P$. halstedii pathotypes were cultured, characterized, harvested and intermediately stored as described earlier [1]. Isolates of $P$. halstedii used in this study are listed in Table 1. Sporangium samples are deposited in the Oomycetes collection of O. Spring, University of Hohenheim and stored at $-70^{\circ} \mathrm{C}$. Vouchers of field collections of downy mildew infected sunflower are deposited in the Hohenheim herbarium (HUH) under the collection numbers \#405 (Waldenbuch, Germany, 2001), \#406 (Wurmlingen, Germany, 2001), \#407 (Steinenbronn, Germany, 2001), \#530 (Balcarce, Argentina, 2003) and \#1057 (Plieningen, Germany, 2008).

\section{Virus extraction and purification}

Virus extraction was based on former experiments [10] and was empirically adjusted to precipitate adequate amounts of PhV.

At least $180 \mathrm{~g}$ of frozen sunflower tissue (primary foliage leaves, cotyledones and stems) infected with different isolates of $P$. halstedii was used to purify virions. Per $1 \mathrm{~g}$ infected sunflower tissue, $2 \mathrm{ml} 0.05 \mathrm{M}$ sodium phosphate buffer, pH 7.0 were added. Additionally, $0.3 \%(\mathrm{w} / \mathrm{v})$ of disodium sulfite was added and dissolved by stirring before the sunflower tissue was finely homogenized with an electrical blender. The homogenate was squeezed through four layers of cheesecloth and then centrifuged (5000 g, $4^{\circ} \mathrm{C}, 15$ minutes). To the supernatant, 0.5 M sodium chloride was added and dissolved by stirring at room temperature. PEG 6000 was gradually added to a final ratio of $12 \%(\mathrm{w} / \mathrm{v})$ and the suspension was stirred for an hour before the precipitation was conducted at $4^{\circ} \mathrm{C}$ for 60 hours. The suspension was centrifuged $\left(7000 \mathrm{~g}, 4^{\circ} \mathrm{C}, 30 \mathrm{~min}\right)$ and the precipitate was re-suspended in $1 / 100$ of the original volume of $0.05 \mathrm{M}$ sodium phosphate buffer, $\mathrm{pH} 7.0$ with additional $0.3 \%(\mathrm{w} / \mathrm{v})$ disodium sulfite. To remove contaminants like ribosomes [11], 20\% (v/v) chloroform was added and mixed with the re-suspension. A low-speed centrifugation step (1000 g, $\left.4^{\circ} \mathrm{C}, 5 \mathrm{~min}\right)$ was performed to separate virus-containing aqueous from the organic phase. The chloroform extraction step was repeated once.

Table 1 Characteristics of Plasmopara halstedii isolates used in this study as well as sequence data for viral RNA1 and RNA2.

\begin{tabular}{|c|c|c|c|c|c|c|c|c|}
\hline \multicolumn{3}{|c|}{ P. halstedii isolate/viral isolate } & \multicolumn{2}{|c|}{$\begin{array}{c}\text { Characteristics of } \\
P . \text { halstedii }\end{array}$} & \multicolumn{4}{|c|}{ Analyzed $P$. halstedii virus sequences } \\
\hline & Year of collection & Geographic origin $^{2}$ & Pathotype & Metalaxyl $^{3}$ & RNA1 & Accession & RNA2 & Accession \\
\hline Ph4-93 & 1993 & Fargo, ND, USA & 710 & * & $1921 \mathrm{nt}$ & [GenBank:HM453717] & $1446 \mathrm{nt}$ & [GenBank:HM453722] \\
\hline Ph1-97 & 1997 & Groß Gerau, GER & 330 & * & * & - & $1445 \mathrm{nt}$ & [GenBank:HM453723] \\
\hline Ph9-98 & 1998 & Leinfelden, GER & 310 & sensitive & $1921 \mathrm{nt}$ & [GenBank:HM453716] & $1445 \mathrm{nt}$ & [GenBank:HM453720] \\
\hline Ph8-99 ${ }^{1}$ & 1999 & Bléré, FRA & 710 & resistant & $2793 \mathrm{nt}$ & [GenBank:HM453713] & $1526 \mathrm{nt}$ & [GenBank:HM453718] \\
\hline Ph1-00 & 2000 & Clermond-Ferrand, FRA & 703 & sensitive & $1921 \mathrm{nt}$ & [GenBank:HM453715] & $1445 \mathrm{nt}$ & [GenBank:HM453721] \\
\hline Ph10-00 & 2000 & Poutoux, FRA & 710 & resistant & * & - & $1445 \mathrm{nt}$ & [GenBank:HM453725] \\
\hline Ph19-01 & 2001 & Gödöllö, HUN & 100 & * & $2430 \mathrm{nt}$ & [GenBank:HM453714] & $1445 \mathrm{nt}$ & [GenBank:HM453719] \\
\hline Ph5-05 & 2005 & Jülich, GER & 710 & resistant & * & - & $1446 \mathrm{nt}$ & [GenBank:HM453724] \\
\hline
\end{tabular}

* not determined

${ }^{1}$ Complete nucleotide sequences were established for this viral isolate.

2 HUN: Hungary, GER: Germany, FRA: France, USA: United States of America

${ }^{3}$ P. halstedii isolate is either resistant or sensitive to fungicide treatment with metalaxyl [18]. 
Success of the virus extraction and purification procedure was controlled by negative staining for transmission electron microscopy as described earlier [1].

The virus suspension was divided into aliquots and stored at $-70^{\circ} \mathrm{C}$. Under these conditions, virus suspensions were suitable for RNA extraction, purification and reverse transcription PCR (RT-PCR) experiments for more than three years.

\section{Protein extraction and mass spectrometry}

Extraction of $\mathrm{CP}$ of $\mathrm{PhV}$ was carried out as described earlier [1]. Samples for nano-LC-ESI-MS analysis were further purified on $10 \%$ polyacryl amide gels [12] on a Mini-Protean System (Bio-Rad Laboratories, München, Germany) and stained with coomassie brilliant-blue (Roti-Blue, Carl Roth, Karlsruhe, Germany).

Gel bands of the CP were in-gel-digested using trypsin (Roche, Penzberg, Germany) [13]. After tryptic digestion, the supernatant was recovered and the gel pieces were extracted with 50\% acetonitrile (ACN)/50\% 0.1\% formic acid (FA) (v/v). The pooled supernatants were then dried in a vacuum centrifuge and stored intermediately at $-20^{\circ} \mathrm{C}$.

Nano-LC-ESI-MS/MS experiments were performed on an ACQUITY nano-UPLC system (Waters, Milford, USA) directly coupled to a LTQ-Orbitrap XL hybrid mass spectrometer (Thermo Fisher, Bremen, Germany). Tryptic digests of the PhV CP were concentrated and desalted on a precolumn $(2 \mathrm{~cm} \times 180 \mu \mathrm{m}$, Symmetry C18, $5 \mu \mathrm{m}$ particle size; Waters, Milford, CT) and separated on a $20 \mathrm{~cm} \times 75 \mu \mathrm{m} \mathrm{BEH} 130 \mathrm{C} 18$ reversed phase column (1.7 $\mu \mathrm{m}$ particle size; Waters, Milford, CT) using a linear gradient of 1 to $50 \% \mathrm{ACN}$ in $0.1 \% \mathrm{FA}$ within $1 \mathrm{~h}$. The LTQ-Orbitrap was operated under the control of XCalibur 2.0.7 software. Survey spectra $(\mathrm{m} / \mathrm{z}$ $=250-1800)$ at a resolution of 60.000 at $\mathrm{m} / \mathrm{z}=400$ were detected in the Orbitrap using lock-mass ions from ambient air for internal calibration [14]. Data-dependent tandem mass spectra were generated for the five most abundant peptide precursors in the linear ion trap.

Mascot 2.2 software (Matrix Science, London, UK) was used for protein identification. Spectra were searched against the NCBI protein sequence database downloaded as FASTA-formatted sequences from ftp:// ftp.ncbi.nih.gov/blast/db/FASTA/nr.gz and supplemented with the deduced ORF2 amino acid sequence of the PhV CP. Search parameters specified trypsin or "no enzyme" as cleaving enzyme allowing two missed cleavages, a $3 \mathrm{ppm}$ mass tolerance for peptide precursors and 0.6 Da tolerance for fragment ions.

\section{Characterization of the $\mathrm{N}$-terminus of the $\mathrm{CP}$}

Mass spectra of purified PhV CP, in source decay (ISD)and MS/MS-spectra were acquired on a AutoflexIII
MALDI-TOF-TOF mass spectrometer (Bruker Daltonics, Bremen, Germany). The instrument was operated in the positive ion mode and externally calibrated using protein mass or peptide calibration standards (Bruker Daltonics, Bremen, Germany), respectively. PhV CP samples were desalted and concentrated on C4 ZipTips (Millipore, Schwalbach, Germany) following the manufacturer's protocols. Proteins were eluted directly onto a stainless steel target using $1 \mu \mathrm{l}$ of a 2,5-Dihydroxybenzoic acid matrix solution (30 $\mathrm{mg} \mathrm{mL}^{-1}$ in $50 \% \mathrm{ACN} / 50 \%$ $0.1 \%$ TFA, v/v). Molecular masses of intact CP was obtained in the linear mode using an accelerating voltage of $20 \mathrm{kV}$ with 1000 laser shots per sample to ensure good $\mathrm{S} / \mathrm{N}$ ratio.

ISD-spectra and MS/MS-spectra (T3-Sequencing = terminus-specific pseudo-MS3 TOF-TOF analysis) of $\mathrm{PhV} \mathrm{CP}$ were acquired in the reflector mode using an accelerating voltage of $20 \mathrm{kV}$. In order to achieve a good S/N ratio, 3000 and 2000-3000 laser shots were recorded for reflector-ISD and MS/MS spectra, respectively. Data were analyzed using Flex Analysis 3.0 and Bio-Tools 3.0 software (Bruker Daltonics, Bremen, Germany) taking into account the deduced amino acid sequence from ORF2 of PhV.

\section{Nucleic acid extraction}

Viral ssRNA was extracted from purified virions, $P$. halstedii sporangia or herbarium specimens of $P$. halstedii infected sunflower using the Aurum Total RNA Mini Kit (Bio-Rad Laboratories, Hercules, CA) according to the manufacturer's protocols. RNA sample purity was checked spectroscopically ( $\mathrm{A}_{260} / \mathrm{A}_{280}$ ratio).

Viral dsRNA was extracted and purified from $P$. halstedii infected sunflower tissue [15].

\section{cDNA synthesis, primers, PCR and sequencing}

cDNA synthesis was performed using either the First Strand cDNA Synthesis Kit or RevertAid First Strand cDNA Synthesis Kit (both kits: Fermentas, Glen Burnie, MD). A first fragment of RNA2 was obtained as stated earlier [1].

$\mathrm{PhV}$ specific primers used for sequence comparison were summarized in Table 2.

The PCR standard protocol was $94^{\circ} \mathrm{C}$ for $2 \mathrm{~min}$; then 35 cycles of $94^{\circ} \mathrm{C}$ for $45 \mathrm{~s}, 54^{\circ} \mathrm{C}$ for $45 \mathrm{~s}, 72^{\circ} \mathrm{C}$ for $1 \mathrm{~min}$ $15 \mathrm{~s}$; and a finale elongation step at $72^{\circ} \mathrm{C}$ for $10 \mathrm{~min}$. Occasionally, a gradient thermal cycler set at different annealing temperatures was used to optimize the yield of PCR products.

PCR products were analyzed on $1 \%$ agarose gels $(1 \times$ TBE buffer, ethidium bromide staining) and then purified (Qiaquick PCR Purification Kit; Qiagen, Valencia, CA). The purified PCR products were either directly sequenced with virus-specific primers or cloned in $E$. 
Table 2 Primers specifically designed for Plasmopara halstedii virus (PhV) which were used for sequence comparison.

\begin{tabular}{|c|c|c|c|}
\hline \multicolumn{4}{|c|}{ PhV forward primers $\left(5^{\prime} \rightarrow 3^{\prime}\right)$} \\
\hline & RNA1 primer sequence & & RNA2 primer sequence \\
\hline $1-\mathrm{f3}$ & ATT TAC CGT GTT GCT GGA GG & $2-f 3$ & CTG GGT AGT GGA GAC TAC ACA \\
\hline $1-f 12$ & CAC TAA CTA ACG CTT TCT GTG CT & $2-f 22$ & ACG CAG GAA AAC GAG GAA G \\
\hline $1-f 34$ & GCC AGG GAT GTT GGT AGA GA & $2-f 28$ & ATT GTC CAA CGT AGC CTT CG \\
\hline $1-f 39$ & TAC CAC AAT CGA AGG GTC AAG & $2-\mathrm{f} 30$ & GCA ATC GCG TCG ACA AA \\
\hline $1-f 42$ & CTT TCC GAC CTG AAT ACA CGA & $2-\mathfrak{f 3 1}$ & AGC GTG CCT ACT GAG GAT TC \\
\hline $1-f 43$ & CCA CTG TGT GGC ACG ATT AC & $2-f 32$ & AGC CGG TGG ATC TGT AAA TG \\
\hline $1-f 44$ & AAA GAG TGC TGG CGT TAC AGC & $2-f 33$ & GTT TTG GCG GAT TGG AAG TA \\
\hline $1-f 45$ & GAC CAT TTC AAC CGG TAA GG & & \\
\hline \multicolumn{4}{|c|}{ PhV reverse primers $\left(5^{\prime} \rightarrow 3^{\prime}\right)$} \\
\hline & RNA1 primer sequence & & RNA2 primer sequence \\
\hline $1-r 17$ & GAA TाT GGA TAA AGC CCG AA & $2-\mathrm{f} 3 \mathrm{rc}$ & TGT GTA GTC TCC ACT ACC CAG \\
\hline $1-r 24$ & TAG GGA CGC TAA AGC AGC AT & $2-r 4$ & CGA GAC AGT TGC GTT GGA \\
\hline $1-r 25$ & TAT TTG GTG GTC TGC ATC CA & $2-r 18$ & CAG TGG AAC GGT ATG ACG TG \\
\hline \multirow[t]{2}{*}{$1-r 48$} & ATA GCA GTC AAT CCC GCA CT & $2-r 24$ & GTC TCC CCC AAC CAT TAT GA \\
\hline & & $2-r 27$ & TAT TGT GCA AAC CCA CTC GA \\
\hline
\end{tabular}

coli (StrataClone PCR U/A Cloning Kit, Stratagene, La Jolla, CA), isolated (GeneJet Plasmid Miniprep Kit; Fermentas, Glen Burnie, MD) and sequenced with standard primers. All sequences were at least once verified with another primer.

Using a gradient thermal cylcer, a primer set for RNA2 (2-r7: 5'-AAG CGC GGC GTT TGT -3' and 2-f9: 5'-CAA AGC GTC TCC CAT TGG - 3') resulted in two additional DNA fragments $(0.8 \mathrm{~kb}$ and $0.7 \mathrm{~kb}$, respectively) at an annealing temperature of $48^{\circ} \mathrm{C}$. These two additional amplicons were directly sequenced. Their deduced amino acid sequences showed similarity to the deduced amino acid sequence of the RdRp of SmV A. Based upon this similarity, the sequence data of the putative PhV RNA1 were aligned and virus-specific primers were designed to close the gap between these two partial nucleotide sequences.

\section{3' Rapid amplification of CDNA ends (3' RACE)}

The 3' ends of RNA1 and RNA2 were determined when viral RNA was transcribed into cDNA with an adaptor (5'-ATG ACT CGA GTC GAC ATC GAT TTT TTT TTT TTT TTT TTT TTT TTT TTV N -3') which included a poly(T) tract (adaptor and adaptor-specific primer modified after Sambrook and Russell, 2001). After its synthesis, cDNA was amplified in PCR with virus-specific forward primers and an adaptor-specific reverse primer (5'-ATG ACT CGA GTC GAC ATC GA -3'). PCR products were cloned in $E$. coli and sequenced with virus-specific forward primers. Control experiments with $E$. coli poly(A) polymerase (NewEngland Biolabs, Ipswich, MA) indicated the lack of internal annealing sites for poly $(\mathrm{T})$, thus confirming that both viral RNA segments featured a poly(A) tract at their 3' ends.

\section{5' Rapid amplification of cDNA ends (5' RACE)}

The 5' ends were determined using the SMART RACE cDNA Amplification Kit (Clontech Laboratories, Carlsbad, CA).

A second 5' RACE technique based on purified viral dsRNA was carried out [16] in order to ascertain the 5' ends of RNA1 and RNA2. The results of the second 5' RACE experiments confirmed the 5' sequence of the RNA1 segment. For the RNA2 segment, the 5' end determined with the SMART RACE-kit was extended by additional $44 \mathrm{nt}$.

\section{Comparative sequence analysis}

Viral RNA of different $P$. halstedii isolates was transcribed into cDNA using random hexamer primers. PCR was then conducted using primer sets for RNA1 and RNA2, respectively. After submitting the PCR product to agarose gel electrophoresis, a single DNA fragment resulted for each primer pair. These fragments were purified and directly sequenced using one primer of the corresponding primer pair for sequencing. Both strands were sequenced at least twice.

\section{Sequence analysis}

Sequence data were subjected to BLAST analysis and aligned using the software BioEdit (version 7.0.5.3; Hall, 1999). The GenBank accession numbers for the different $\mathrm{PhV}$ isolates are given in Table 1 . The GenBank accession numbers for SmV A are AB083060 (RNA1), AB083061 (RNA2) and AB083062 (RNA3). 


\section{Results and discussion Genome organization}

Based on the recent comparison of a partial nucleotide sequence of $\mathrm{PhV}$ in various samples of $P$. halstedii [1], the viral isolate Ph8-99 was selected for complete sequencing of the two ssRNA segments and genome analysis.

RNA1 consisted of 2793 nt excluding the 3' poly(A) tract. Analysis of the determined nucleotide sequence revealed the existence of one large ORF (ORF1) of 2745 nt (914 amino acid residues). The estimated molecular mass of the protein encoded by ORF1 was $104 \mathrm{kDa}$. RNA1 had a 5'-untranslated region (5' UTR) of $18 \mathrm{nt}$ and a 3'-untranslated region (3' UTR) of $30 \mathrm{nt}$. Analysis of the deduced amino acid sequence of ORF1 revealed the presence of the putative $\mathrm{RdRp}$ domain containing the GDD motif.

RNA2 consisted of 1526 nt excluding the 3' poly(A) tract. Analysis of the determined nucleotide sequence revealed the existence of one ORF (ORF2) of $1128 \mathrm{nt}$. The estimated molecular mass of the protein encoded by ORF2 was $40 \mathrm{kDa}$ (375 amino acid residues). RNA2 had a 5' UTR of $164 \mathrm{nt}$ and a 3' UTR of $234 \mathrm{nt}$. A sequence comparison with data of SmV A [3] and other sequences indicated that ORF 2 encoded for the viral $\mathrm{CP}$ of $\mathrm{PhV}$.

\section{Coat protein (CP) characterization}

A molecular mass of the CP of ca. $37.5 \mathrm{kDa}$ [8] to 36 $\mathrm{kDa}$ [1] was estimated previously by SDS-PAGE analysis. This was in discrepancy with the molecular mass of 40 $\mathrm{kDa}$ calculated for the 375 amino acids deduced from the nucleotide sequence of ORF2. Therefore, the CP band was cut off from an SDS-PAGE-gel, digested with trypsin and analyzed by mass spectrometry. Nano-LCESI-MS/MS analysis showed sequence coverage of $62 \%$ according to the deduced amino acid sequence from ORF2. The first 23 amino acids of the $\mathrm{N}$-terminal sequence of CP were not covered by tryptic peptides and the peptide most proximal to the $\mathrm{N}$-terminus of $\mathrm{CP}$ comprising the amino acids 24-35 (DYTVQSNSIVQR), had a non-tryptic cleavage site at its $\mathrm{N}$-terminus (data not shown). This suggested that the $\mathrm{N}$-terminus of the CP might be proteolytically processed in vivo leading to the lower molecular mass as observed in SDS-PAGE experiments. In order to verify this, the $\mathrm{N}$-terminal sequence of the CP was analyzed by Top-Down MALDI-TOF analysis [17]. Two major in source decay (ISD) fragments of $1479.74 \mathrm{Da}$ and $1765.93 \mathrm{Da}$ were observed by Top-Down MALDI-TOF analysis (Figure 1A). Fragmentation of the smaller ISD fragment revealed the peptide sequence DYTVQSNSIVQR (Figure $1 \mathrm{~B})$, whereas the larger ISD fragment covered the sequence DYTVQSNSIVQRSLR (data not shown).
Therefore, the Top-Down MALDI-TOF sequence analysis determined the start of the N-terminal sequence of $\mathrm{CP}$ at amino acid 24 and confirmed the result from the nano-LC-ESI-MS/MS experiment.

These results suggest that the $\mathrm{CP}$ of $\mathrm{PhV}$ is processed in vivo at its $\mathrm{N}$-Terminus by a yet unknown protease to a final size of 352 amino acids and a mass of $38.0 \mathrm{kDa}$ which is in consistency with the results obtained by SDS-PAGE analysis. Similar processing of the N-terminus was assumed for CP2 of SmV A [3].

\section{Viral nucleotide sequence comparison among different isolates of $P$. Halstedii}

Variation in the nucleotide sequences of PhV from $P$. halstedii isolates of different pathogenicity and origin was assessed using virus-specific primers for large fragments of both RNA segments.

Seven representative $P$. halstedii virus isolates (Ph4-93, Ph1-97, Ph9-98, Ph1-00, Ph10-00, Ph19-01 and Ph5-05) were chosen to be partially sequenced (Table 1). A 1.4 kb-sequence of RNA2 and a $1.9 \mathrm{~kb}$-sequence of RNA1 were compared to the complete sequence of $P$. halstedii virus isolate Ph8-99 and compared among themselves. Accounting for more than three quarters of the total genome of $P$. halstedii virus, sequence variation was extremely low.

In terms of RNA1, the two French isolates (Ph8-99 and Ph1-00) were identical. The samples from Germany (Ph9-98), Hungary (Ph19-01), and the USA (Ph4-93) each differed from isolate $\mathrm{Ph} 8-99$ in single nucleotides at different positions. Only the sequence variation in the German sample led to an amino acid exchange in the deduced amino acid sequence.

In terms of RNA2, Ph8-99 differed in a single nucleotide from all other samples causing an amino acid exchange from alanine to valine. The Hungarian isolate Ph19-01 differed from isolate Ph8-99 in one nucleotide which led to an amino acid exchange from isoleucine to methionine. The French isolate Ph1-00 differed from Ph8-99 in two nucleotides causing a single amino acid exchange from glutamine to serine. The German isolate Ph5-05 showed one nucleotide insertion in the 3'-UTR and additionally one nucleotide exchange. The US isolate Ph4-93 showed only the nucleotide insertion like the German isolate Ph5-05 but not the additional nucleotide exchange. Since the insertion took place in the 3'-UTR, the frameshift was without consequences for the structure or function of the CP.

It appeared that alterations in these highly conserved sequences of RNA1 and RNA2 are detrimental for the self-assembly process during virus propagation.

Additionally five infected herbarium specimens of sunflower were tested to fathom the applicability of $\mathrm{PhV}$ 
A
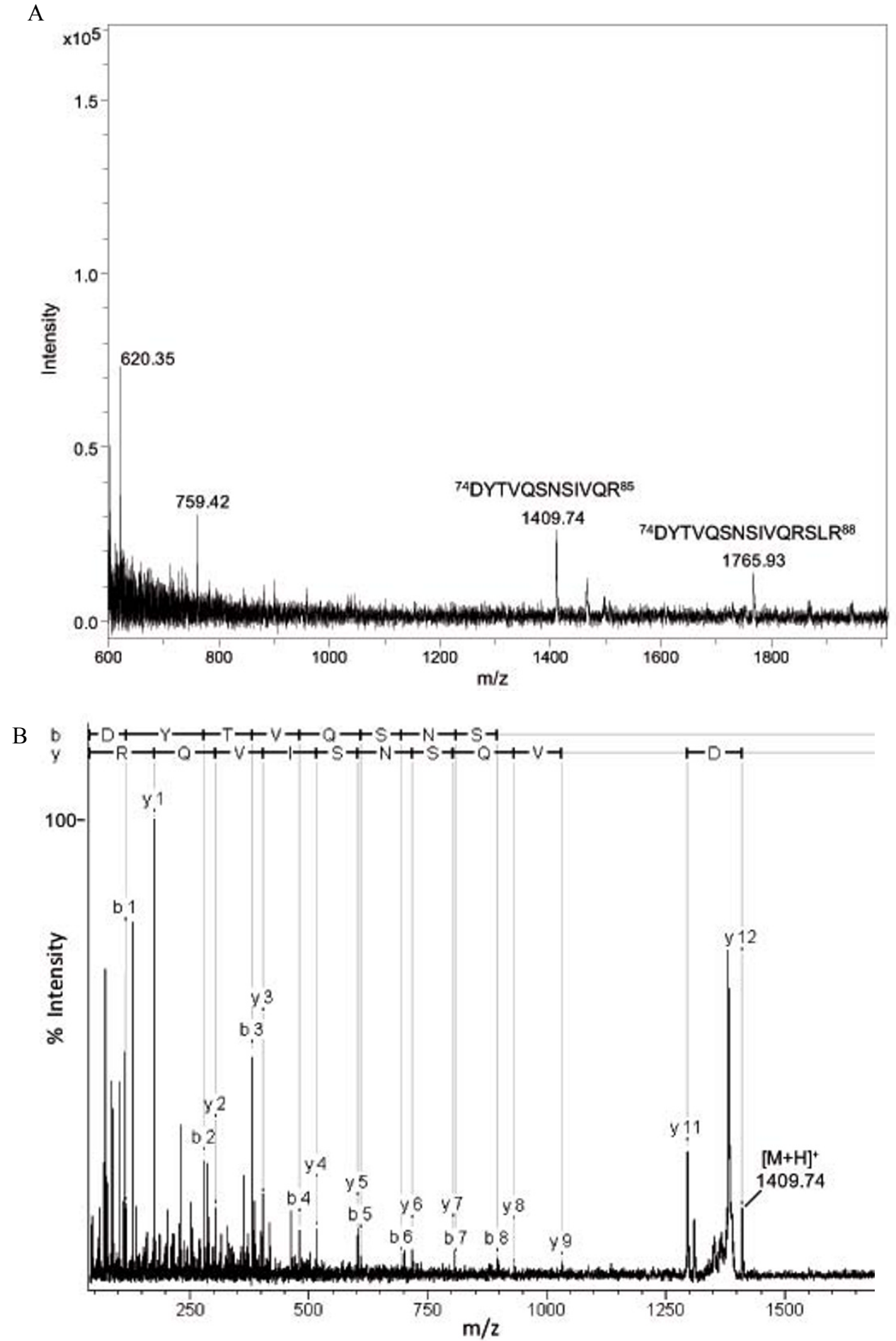

Figure 1 Mass spectroscopic analysis of the coat protein (CP) of Plasmopara halstedii virus (PhV). A Reflector ISD-MALDI-TOF spectrum. The N-terminal sequence of the intact PhV CP was analyzed by Top-Down MALDI-TOF mass spectrometry. The in source decay (ISD) spectrum shows two major ISD fragment ions of the PhV CP with masses of 1409.74 Da and 1765.93 Da, respectively. These ISD fragment ions masses fit to sequences D74-R85 and D74-R88 of the deduced amino acid sequence of the PhV CP, respectively. The corresponding amino acid sequences of the ISD fragment ions were shown. B MS/MS spectrum of the 1409.74 Da ISD-fragment. The N-terminal sequence of PhV CP DYTVQSNSIVQR deduced from the reflector ISD spectrum (Fig. 1A) was confirmed by MS/MS analysis of the 1409.74 Da ISD fragment ion. The observed b- and $y$-fragment ions are annotated in the spectrum and the corresponding amino acid sequence covered by b- and $y$-ions were shown. 
sequence population studies on a broader set of samples. The herbarium specimens were stored in the herbarium of the University of Hohenheim for up to nine years. Small fragments between 410 and $650 \mathrm{nt}$ of RNA2 were amplified and sequenced. Again, the sequence variation of the virus in these herbarium specimens was insignificant (data not shown).

The results of this study suggested the presence of a single virus in the tested $P$. halstedii isolates.

\section{Comparison of $\mathrm{PhV}$ with other viruses}

A preliminary study revealed that $\mathrm{PhV}$ and $\mathrm{SmV}$ A shared several morphological, biochemical and molecular characteristics. Both viruses were isometric and showed a granular surface. $\mathrm{PhV}$ measured ca. $37 \mathrm{~nm}$ in diameter, whereas $\mathrm{SmV}$ A was slightly larger (ca. $40 \mathrm{~nm}$ in diameter). Both viral genomes are encoded in ssRNA. In $\mathrm{SmV}$ A, three RNA segments were detected whereas PhV only contained two segments [1,3-5]. The genome organization was now studied and compared to other viruses.

SmV A RNA1 with 2928 nt coded for the RdRp on ORF1a and another protein of unknown function in ORF1b. In PhV, RNA1 with its 2793 nt (excluding the 3' poly(A) tract) coded analogously for the RdRp. ORF1b as it was found in SmV A was not determined in PhV RNA1 (Table 3).

The deduced amino acid sequence of PhV ORF1 $(\mathrm{RdRp})$ showed similarity of ca. $47 \%$ to the deduced amino acid sequence of SmV A ORF1a (RdRp). Moreover, an amino acid sequence similarity of ca. $40 \%$ was observed between PhV RdRp and RdRp of viruses within

Table 3 Comparison of Plasmopara halstedii virus (PhV) and Sclerophthora macrospora virus A (SmV A).

\begin{tabular}{|c|c|c|}
\hline \multicolumn{2}{|l|}{ Morphology } & SmV A \\
\hline Virion diameter (stained with $2 \%$ uranyl acetate) & $37 \mathrm{~nm}$ & $40 \mathrm{~nm}$ \\
\hline Virion shape & isometric & isometric \\
\hline Presence or absence of peplomers & present & present \\
\hline \multicolumn{3}{|l|}{ Genome } \\
\hline Type of nucleic acid & RNA & RNA \\
\hline Strandedness & single-stranded & single-stranded \\
\hline Size of genome & $4.3 \mathrm{~kb}$ & $5.9 \mathrm{~kb}$ \\
\hline Number of segments & 2 & 3 \\
\hline $\mathrm{G}+\mathrm{C}$ ratio & $\begin{array}{l}\text { RNA1: } 45 \% \\
\text { RNA2: } 48 \% \\
-\end{array}$ & $\begin{array}{l}\text { RNA1: } 51 \% \\
\text { RNA2: } 49 \% \\
\text { RNA3: } 51 \%\end{array}$ \\
\hline Size of segments and open-reading frames (ORF) & $\begin{array}{l}\text { RNA1: } 2793 \text { nt (ORF1) } \\
\text { RNA2: } 1526 \text { nt (ORF2) } \\
-\end{array}$ & $\begin{array}{l}\text { RNA1: } 2928 \text { nt (ORF1a, ORF1b) } \\
\text { RNA2: } 1981 \text { nt (ORF2) } \\
\text { RNA3: } 977 \text { nt (no ORF) }\end{array}$ \\
\hline $\begin{array}{l}\text { Size and function of ORF } \\
\text { RdRp: RNA-dependent RNA polymerase } \\
\text { CP: Coat protein }\end{array}$ & $\begin{array}{c}\text { ORF1: } 2745 \text { nt (RdRp) } \\
- \\
\text { ORF2: } 1128 \text { nt (CP) }\end{array}$ & $\begin{array}{c}\text { ORF1a: } 2697 \mathrm{nt} \text { (RdRp) } \\
\text { ORF1b: } 870 \text { nt (unknown function) } \\
\text { ORF2: } 1269 \text { nt (CP) }\end{array}$ \\
\hline Size of $5^{\prime}$ untranslated region (5' UTR) & $\begin{array}{l}\text { RNA1: } 18 \mathrm{nt} \\
\text { RNA2: } 164 \mathrm{nt}\end{array}$ & $\begin{array}{l}\text { RNA1: } 66 \mathrm{nt} \\
\text { RNA2: } 11 \mathrm{nt}\end{array}$ \\
\hline Size of $3^{\prime}$ untranslated region ( $3^{\prime}$ UTR) & $\begin{array}{l}\text { RNA1: } 30 \mathrm{nt} \\
\text { RNA2: } 234 \mathrm{nt}\end{array}$ & $\begin{array}{l}\text { RNA1: } 165 \mathrm{nt} \\
\text { RNA2: } 701 \mathrm{nt}\end{array}$ \\
\hline 3'-terminal poly(A) tract & Poly $(A)$ tracts are present in RNA1 and RNA2. & $\begin{array}{l}\text { Poly }(\mathrm{A}) \text { tracts are lacking } \\
\text { at the } 3^{\prime} \text { ends of all } 3 \text { RNA. }\end{array}$ \\
\hline \multicolumn{3}{|l|}{ Proteins } \\
\hline Number of structural proteins & 1 & 2 \\
\hline Size of structural proteins & $\begin{array}{l}\text { SDS-PAGE: } 36 \mathrm{kDa} \\
\text { ORF2: } 40 \mathrm{kDa} \text { ( } 375 \text { amino acids) } \\
\text { Postproteolytic cleavage: } 38 \mathrm{kDa}\end{array}$ & $\begin{array}{l}\text { SDS-PAGE: } 43 \mathrm{kDa} \text { and } 39 \mathrm{kDa} \\
\text { ORF2: } 45 \mathrm{kDa} \text { (422 amino acids) } \\
\text { Postproteolytic cleavage: } 38 \mathrm{kDa}\end{array}$ \\
\hline $\mathrm{CP}$ shows similarities to $\mathrm{CP}$ of... & SmV A, Tombusviruses & PhV, Tombusviruses \\
\hline Number of non-structural proteins & 1 & $1-2$ \\
\hline Size of non-structural proteins & ORF1: 914 amino acids (104 kDa) & $\begin{array}{l}\text { ORF1a: } 898 \text { amino acids (100 kDa) } \\
\text { ORF1b: } 289 \text { amino acids (33 kDa) }\end{array}$ \\
\hline $\begin{array}{l}\text { RdRp shows similarities to RdRp of... } \\
\text { Lipids }\end{array}$ & SmV A, Nodaviruses & PhV, Nodaviruses \\
\hline Content, character, etc. & none & not determined \\
\hline
\end{tabular}


the Nodaviridae family (e.g. Barfin flounder nervous necrosis virus, Striped Jack nervous necrosis virus).

RNA2 of SmV A with a length of $1981 \mathrm{nt}$ coded for the two CP. In PhV, RNA2 of 1526 nt (excluding the 3' poly(A) tract) was found to code for the single CP (Table 3). Between ORF2 of PhV and SmV A ORF2, amino acid sequence similarity of ca. $56 \%$ was observed. Within the first ten amino acids at the $\mathrm{N}$-terminal sequences, PhV CP (DYTVQSNSIV) and CP2 of SmV A (DYKVSQNSLV) featured six identical amino acid residues. Two other amino acid QS (PhV) and SQ (SmV A), respectively, were interchanged. Amino acid sequence similarity of ca. $37 \%$ was observed between the $\mathrm{CP}$ of $\mathrm{PhV}$ and the $\mathrm{CP}$ of viruses within the Tombusviridae (e.g. Pelargonium leaf curl virus, Tomato bushy stunt virus).

In PhV, RNA1 and RNA2 both had poly(A) tracts at their 3' termini whereas in $\mathrm{SmV}$ A poly(A) tracts were lacking at the 3'-termini of all three viral RNA (Table 3).

\section{Conclusions}

The complete nucleotide sequence of $\mathrm{PhV}$ was established. PhV showed similarities to $\mathrm{SmV}$ A and viruses within the Tombusviridae family as well as Nodaviridae family.

The sequence data of several viral isolates suggested that there was a single virus type in different $P$. halstedii isolates. Viral sequence variation did not account for different pathotypes of the oomycete $P$. halstedii.

\footnotetext{
Acknowledgements

Dr. Ray Hammerschmidt and Dr. Dennis W. Fulbright (both: Department of Plant Pathology, Michigan State University, East Lansing, Michigan, USA) is thanked for kindly accepting Marion as a visiting scholar in their laboratories. Helpful advice of Dr. Artur J.P. Pfitzner (Department of Genetics, University of Hohenheim, Stuttgart, Germany) regarding 5'-RACE is gratefully

acknowledged. We thank Iris Klaiber (Zentrale Serviceeinheit des Life Science Centers, University of Hohenheim, Stuttgart, Germany) for protein mass spectrometry. We also thank Reinhard Zipper (Institute for Botany, University of Hohenheim, Stuttgart, Germany) for his assistance. Our research was financially supported by Deutsche Forschungsgemeinschaft (DFG; SP292/211).
}

\section{Author details}

${ }^{1}$ Institute of Botany, University of Hohenheim, 70593 Stuttgart, Germany. 2Department of Plant Pathology, Michigan State University, East Lansing, Michigan, USA. ${ }^{3}$ Institute of Physiology, University of Hohenheim, 70593 Stuttgart, Germany.

\section{Authors' contributions}

MHD carried out most of the experiments, analyzed the sequences and drafted the manuscript. JCG participated in designing the experiments, extracted viral dsRNA and coat protein and carried out further experiments.

JP analyzed the viral coat protein and prepared the respective portion of the manuscript. OS coordinated this study, assisted sequence analysis and

helped preparing the manuscript.

All authors have read and approved the final manuscript.

\section{Competing interests}

The authors declare that they have no competing interests.
Received: 1 December 2010 Accepted: 17 March 2011

Published: 17 March 2011

\section{References}

1. Heller-Dohmen M, Göpfert JC, Hammerschmidt R, Spring O: Different pathotypes of the sunflower downy mildew pathogen Plasmopara halstedii all contain isometric virions. Molecular Plant Pathology 2008 9(6):777-786.

2. Yokoi T, Takemoto Y, Suzuki M, Yamashita S, Hibi T: The nucleotide sequence and genome organization of Sclerophthora macrospora Virus B. Virology 1999, 264:344-349

3. Yokoi T, Yamashita S, Hibi T: The nucleotide sequence and genome organization of Sclerophthora macrospora Virus A. Virology 2003, 311:394-399.

4. Honkura R, Shirako Y, Ehara Y, Yamanaka S: Two types of virus-like particles isolated from downy mildew diseased rice plants. Ann Phytopath Soc Japan 1983, 49:653-658.

5. Shirako $Y$, Ehara $Y$ : Composition of viruses isolated from Sclerophthora macrospora-infected rice plants. Ann Phytopath Soc Japan 1985, 51:459-464.

6. Gulya TJ: Distribution of Plasmopara halstedii races from sunflower around the world. In Advances in Downy Mildew Research. Volume 3. Edited by: Lebeda A. Spencer-Phillips PTN. Palacky University Ollomouc and JOLA, v.o.S., Kostelec na Hane, Czech Republic; 2007:121-134.

7. Gulya TJ, Freeman TP, Mayhew DE: Virus-like particles in Plasmopara halstedii, sunflower downy mildew. Phytopathology 1990, 80:1032.

8. Gulya TJ, Freeman TP, Mayhew DE: Ultrastructure of virus-like particles in Plasmopara halstedii. Can J Bot 1992, 70:334-339.

9. Mayhew DE, Cook AL, Gulya TJ: Isolation and characterization of a mycovirus from Plasmopara halstedii. Can J Bot 1992, 70:1734-1737.

10. Yamamoto KR, Alberts BM, Benzinger R, Lawhorne L, Treiber G: Rapid bacteriophage sedimentation in the presence of polyethylene glycol and its application to large-scale virus purification. Virology 1970, 40:734-744.

11. Hull R: Purification, biophysical and biochemical characterization of viruses with especial reference to plant viruses. In Virology - a practical approach. Edited by: Mahy BWJ. Oxford: IRL Press Ltd.; 1985:1-24.

12. Laemmli UK: Cleavage of structural proteins during the assembly of the head of bacteriophage T4. Nature 1970, 227:680-685.

13. Shevchenko A, Wilm M, Vorm O, Mann M: Mass spectrometric sequencing of proteins silver-stained polyacrylamide gels. Anal Chem 1996, 68:850-858.

14. Olsen JV, de Godoy LM, Li G, Macek B, Mortensen P, Pesch R, Makarov A, Lange $\mathrm{O}$, Horning $\mathrm{S}$, Mann M: Parts per million mass accuracy on an Orbitrap mass spectrometer via lock mass injection into a C-trap. $\mathrm{Mol}$ Cell Proteomics 2005, 4:2010-2021.

15. Thompson JR, Leone G, Lindner JL, Jelkmann W, Schoen CD: Characterization and complete nucleotide sequence of Strawberry mottle virus: A tentative member of the new family of bipartite plant picorna-like viruses. Journal of General Virology 2002, 83:229-239.

16. Sambrook J, Russell DW: Molecular cloning - A laboratory manual. Cold Spring Harbor: Cold Spring Habor Laboratory; 2001

17. Suckau D, Resemann A: T3-sequencing: targeted characterization of the $\mathrm{N}$ - and C-termini of undigested proteins by mass spectrometry. Anal Chem 2003, 75:5817-5824.

18. Spring O, Rozynek B, Zipper R: Leaf disk inoculation - a useful tool for selecting infections of sunflower downy mildew at low inoculum concentration but inappropriate to pathotype characterization. J Phytopathology 1997, 145:189-191.

doi:10.1186/1743-422X-8-123

Cite this article as: Heller-Dohmen et al:. The nucleotide sequence and genome organization of Plasmopara halstedii virus. Virology Journal 2011 8:123. 